\title{
Philasterides dicentrarchi (Ciliophora, Scuticociliatida) as the causative agent of scuticociliatosis in farmed turbot Scophthalmus maximus in Galicia (NW Spain)
}

\author{
R. Iglesias ${ }^{1}$, A. Paramá ${ }^{1}$, M. F. Alvarez ${ }^{1}$ J. Leiro ${ }^{1}$, J. Fernández ${ }^{2}$ M. L. Sanmartín ${ }^{1, *}$ \\ ${ }^{1}$ Laboratorio de Parasitología, Instituto de Investigación y Análisis Alimentarios, Universidad de Santiago de Compostela, \\ 15706 Santiago de Compostela, Spain \\ ${ }^{2}$ INSUIÑA, O Grove, Pontevedra, Spain
}

\begin{abstract}
Two outbreaks of scuticociliatosis affecting farmed turbot Scophthalmus maximus in Galicia are described. Moribund fish showed cutaneous ulcers, darkened skin, swimming behaviour alterations, exophthalmos, and/or abdominal distension as a result of accumulation of ascitic fluid in the body cavity. Ciliates were detected in fresh mounts of practically all organs and tissues, including the blood and ascitic fluid. Histopathological studies revealed severe encephalitis and meningitis (associated with different degrees of softening or liquefaction of the brain), necrosis of the hepatic parenchyme, severe oedema of the intestinal wall, degeneration of muscle fibres, hyperplasia of the branchial epithelium, and/or vascular and perivascular inflammation. In some cases, parasites are surrounded by abundant monocytic and lymphocytic infiltrate. We report the morphological and biometric characteristics of this ciliate, which allow identification as Philasterides dicentrarchi. We discuss possible routes of entry into the host, and environmental factors possibly facilitating infection.
\end{abstract}

KEY WORDS: Philasterides dicentrarchi $\cdot$ Scuticociliatosis $\cdot$ Histophagous ciliates · Farmed turbot · Scophthalmus maximus

Resale or republication not permitted without written consent of the publisher

\section{INTRODUCTION}

The existence of histophagous ciliates of the orders Scuticociliatida and Hymenostomatida with the capacity to feed on cells and tissues of aquatic animals has been known for many years (Bradbury 1996). Of these ciliates, Ichthyophthirius multifiliis and Cryptocarion irritans are obligate parasites that have been recognized for a long time as a cause of significant economic losses in aquaculture. However, most histophagous ciliates are free-living, and are typically scavengers that feed on suspended particulate matter (bacteria, microalgae, protozoa, etc.). Under certain circumstances, these ciliates may behave as facultative parasites,

${ }^{*}$ Corresponding author. E-mail: mpduran@usc.es actively feeding on cells and tissue residues of certain molluscs (Elston et al. 1999), crustaceans and fishes, and living and reproducing within the host tissues. As regards crustaceans, the scuticociliates Anophryoides haemophila and Mesanophrys spp. may cause systemic disease in lobsters (bumper car disease) and crabs respectively (Morado \& Small 1995, Cawthorn et al. 1996). Bumper car disease is among the 3 most important infectious diseases in the American lobster industry (Cawthorn 1997).

In some species of farmed fish (including southern bluefin, sand whiting, Atlantic salmon and sea bass) and aquarium fish, there have been reports of fatal disorders due to histophagous ciliates of the genus Uronema (Cheung et al. 1980, Bassleer 1983, Gill \& Callinan 1997, Munday et al. 1997), Miamiensis 
(Thompson \& Moewus 1964), Tetrahymena (Ferguson et al. 1987, Lom \& Dyková 1992) and Philasterides (Dragesco et al. 1995). The presence of these ciliates in fish tissues has been associated with various pathological changes, including bleeding cutaneous ulcers, dystrophic and necrotic effects in muscle, hypochromic anaemia, and encephalitis associated with softening or liquefaction of brain tissues.

As regards flatfish species in intensive culture, Japanese flounder Paralichthys olivaceus hatcheries in Asia have been affected in recent years by a disease caused by an as-yet-unidentified scuticociliate (Yoshinaga \& Nakazoe 1993). In the case of farmed turbot, 2 episodes of infection by histophagous scuticociliates have been reported (Dyková \& Figueras 1994, Sterud et al. 2000), though the organism(s) responsible have not been identified to date.

Here, we report a study of the somatic and oral infraciliature of the ciliate responsible for 2 outbreaks of scuticociliatosis recently detected in a turbot farm in Galicia (northwest Spain), together with a description of the clinical signs and pathological changes associated with the disease. The morphological and biometric characteristics of the organism in question allow us to classify it as Philasterides dicentrarchi, which has also been reported to cause systemic disease in the European sea bass Dicentrarchus labrax (Dragesco et al. 1995). This is the first report in which a scuticociliate infecting turbot has been identified to species level.

\section{MATERIALS AND METHODS}

Different organs and tissues, including the brain, were dissected out from recently sacrified fish, and examined in squash preparations by phase-contrast microscopy, with the aim of detecting ciliates. In fish with ascites in the body cavity, an abdominocentesis was performed and the aspirated ascitic fluid was examined for the presence of parasites. When ascites was present, the visceral package was exhaustively washed with saline before examination in order to avoid the occurrence of false positives caused by the contamination of the viscera with ciliates from the ascitic fluid. In all cases, we also examined a blood sample obtained from the caudal vein. In some cases, we additionally examined Giemsa-stained smears of ascitic fluid and blood.

For study of the somatic and oral infraciliature, the ciliates were aseptically isolated from the ascitic fluid contained in the abdominal cavity of turbot and maintained under laboratory culture conditions as per Bernard \& Fenchel (1996). Coinciding with the exponential or plateau phase of culture, ciliates were concentrated by centrifugation at $650 \times g$ for $5 \mathrm{~min}$, then stained by the 'wet' Chatton-Lwoff silver nitrate method described by
Foissner (1991). Drawings of the cortical structures were made with the aid of a camera lucida.

The nuclear apparatus was visualized by the method of Coppellotti (1990), although in this case the ciliates were stained with an aqueous solution of $0.4 \mu \mathrm{g} \mathrm{ml}^{-1}$ of 4'-6-diamidine-2-phenylindole (DAPI, Sigma Chemical Co., St. Louis, MO, USA). Examination and measurement of the nuclear apparatus was done with a Zeiss Axioplan microscope (Jena, Germany) equipped with a DAPI filter set (BP 365/12; FT 395; LP 397).

For histological study, tissues were rapidly fixed in $10 \%$ buffered formaldehyde solution, dehydrated through an ethanol series, embedded in Paraplast Plus (Sigma) and sectioned ( 2 to $5 \mu \mathrm{m}$ thick) with a motorized Jung 2065 Supercut microtome (Leica Instruments, Heidelberg, Germany). The sections were stained with haematoxylin and eosin (H\&E) for examination with a light microscope.

For scanning electron microscopy (SEM), the ciliates from ascites were concentrated by centrifugation $(650 \times g$ for $5 \mathrm{~min})$, fixed in $2.5 \%$ glutaraldehyde in cacodylate buffer, post-fixed in $1 \%$ osmium tetroxide, dehydrated through an ethanol series, critical-pointdried and coated with a gold-palladium mixture. The ciliates were then examined in a Leica 440 Stereoscan (Leica, Cambridge, UK).

\section{RESULTS}

\section{Epidemiological data}

Two outbreaks of scuticociliatosis were detected between summer 1999 and spring 2000 in a turbot ongrowing facility on the southwest coast of Galicia (northwest Spain). In the first outbreak, the infection affected turbot (weight above $500 \mathrm{~g}$ ) in only 2 tanks. In the second outbreak, the infection affected 6 tanks containing fishes with a wide range of weight (150 to $1500 \mathrm{~g}$ ). Both outbreaks provoked mortalities of 20 to

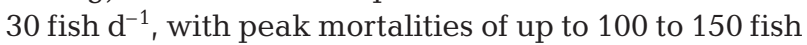
$\mathrm{d}^{-1}$. In some of the affected tanks, the total mortality was $100 \%$, while in others remission was observed 6 to $8 \mathrm{wk}$ after onset. Both tanks affected in the first outbreak were fed by water from a single recirculatory flow system, while some tanks affected in the second outbreak received water directly from the sea, without any sharing or recirculation. Both outbreaks were preceded by periods of high water temperatures $\left(>20^{\circ} \mathrm{C}\right)$.

\section{Ciliate description}

The ciliates are elongated and spindle-shaped, with a tapered anterior and a rounded posterior end, a contractile vacuole and a caudal cilium (Fig. 1A,B; mea- 

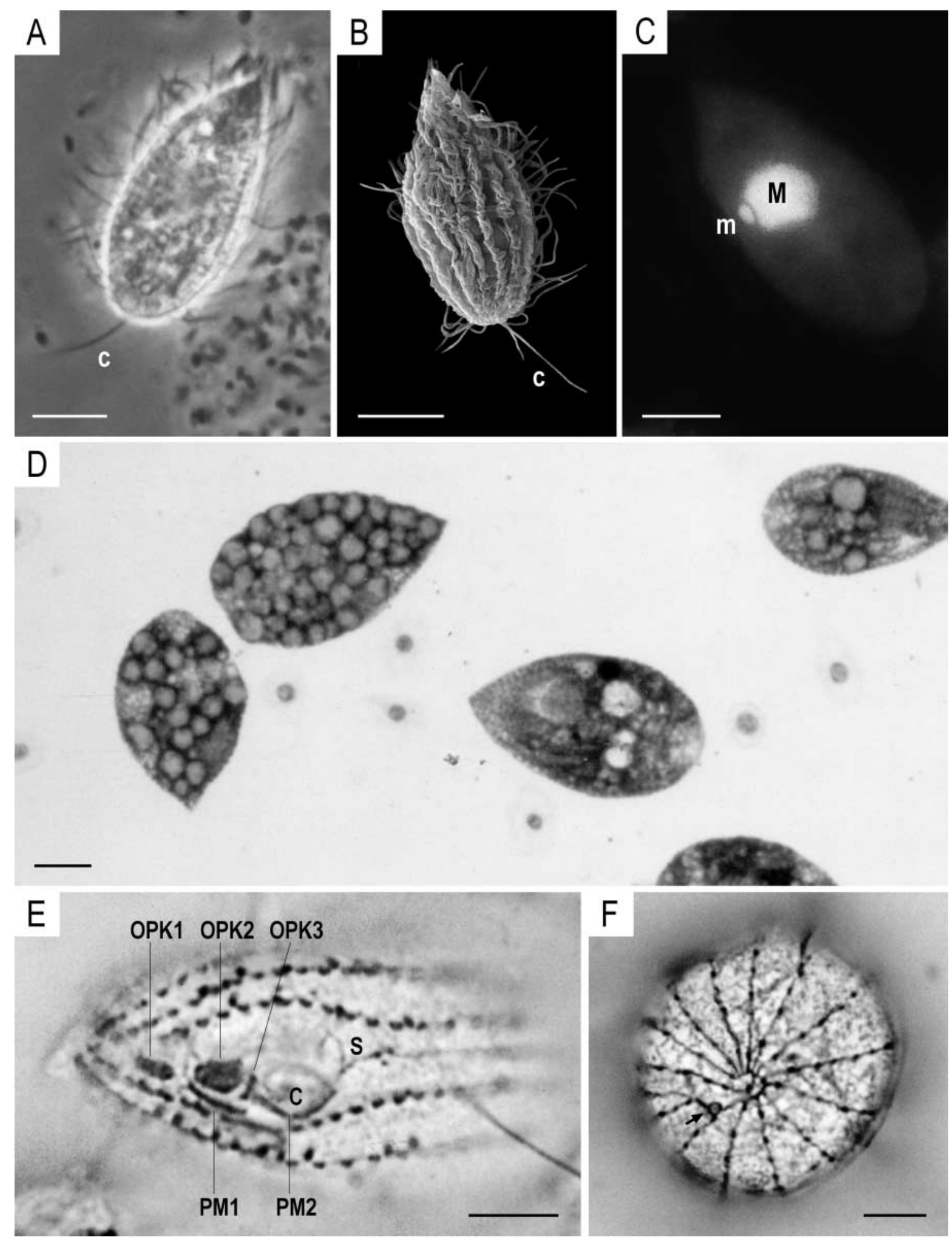

e
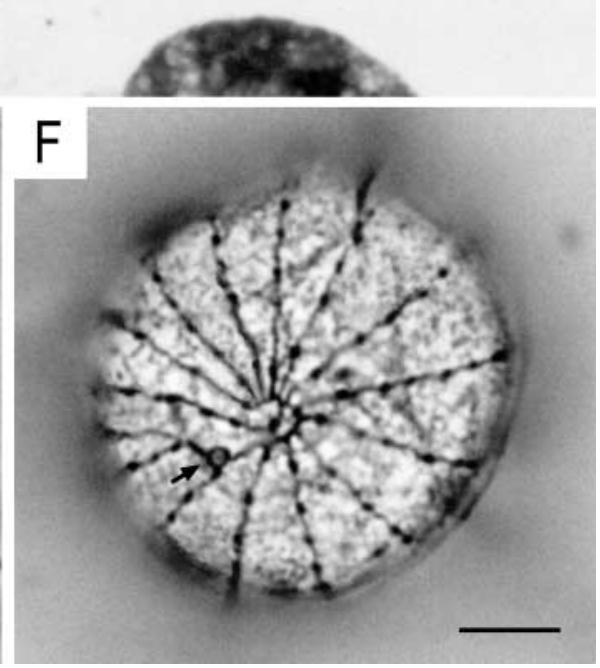

Fig. 1. Morphological characteristics of Philasterides dicentrarchi from farmed turbot. (A) Ciliate observed under phase contrast, showing the long caudal cilium (c) at the posterior end; scale bar $=10 \mu \mathrm{m}$. (B) Scanning electron micrograph of the ciliate with the caudal cilium (c); scale bar $=10 \mu \mathrm{m}$. (C) Nuclear apparatus of the ciliate composed of the macronucleus (M) and micronucleus (m) stained with DAPI; scale bar $=10 \mu \mathrm{m}$. (D) Smear of ascites containing ciliates stained with Giemsa. Note the abundant red blood cells inside the 2 ciliates at the left; scale bar $=10 \mu \mathrm{m}$. (E) Ciliate after wet silver impregnation showing the buccal apparatus composed of paroral membrane (PM) with the 2 parts PM1 and PM2 separated by a narrow gap, the 3 oral polykinetids (OPK1, OPK2 and OPK3) and the cytostome (C), as well as the scutico-vestige (S); scale bar $=5 \mu \mathrm{m}$. (F) Detail of the posterior end of a silverimpregnated ciliate; scale bar $=5 \mu \mathrm{m}$. The circular polar fibre at the center and the pore (arrow) of the posterior vacuole at the base of the second somatic kinety can be observed 
Table 1. Biometric data for silver-impregnated ciliates from turbot with scuticociliatosis. Measurements are in $\mu \mathrm{m}$. PM: paroral membrane; OPK: oral polykinetids

\begin{tabular}{|c|c|c|c|c|}
\hline Character & Mean & $\mathrm{SD}$ & Min & Max \\
\hline Body length & 33.6 & 4.2 & 25 & 43 \\
\hline Body width & 19.5 & 3 & 15 & 28 \\
\hline Caudal cilia length ${ }^{a}$ & 10.7 & 1.1 & 8.7 & 13 \\
\hline Distance apex - post. end PM2 ${ }^{\mathrm{b}}$ & 15 & 1.7 & 11 & 18 \\
\hline Distance apex - ant. end OPK1 & 3.4 & 0.6 & 2.5 & 5 \\
\hline OPK1 length & 2.6 & 0.3 & 2 & 3 \\
\hline OPK1 width & 1 & 0.1 & 1 & 1.3 \\
\hline OPK2 length & 3 & 0.1 & 3.5 & 2.7 \\
\hline OPK2 width & 2 & 0.2 & 1.5 & 2.5 \\
\hline OPK3 length & 0.9 & 0.1 & 0.7 & 1 \\
\hline OPK3 width & 1.7 & 0.1 & 1.5 & 2 \\
\hline Distance OPK1 - OPK2 & 1.3 & 0.2 & 1 & 1.7 \\
\hline Distance OPK2 - OPK3 & 0.4 & 0.1 & 0.3 & 0.7 \\
\hline PM1 length & 3.9 & 0.2 & 3.5 & 4.5 \\
\hline PM2 length & 5 & 0.5 & 4 & 6 \\
\hline Macronucleus long diameter & 7 & 1 & 5 & 9 \\
\hline Macronucleus short diameter & 5.4 & 0.7 & 4 & 7 \\
\hline Micronucleus long diameter & 2.1 & 0.3 & 2 & 3 \\
\hline Micronucleus short diameter & 1.4 & 0.5 & 1 & 2 \\
\hline \multicolumn{5}{|c|}{$\begin{array}{l}\text { a Measured in fixed (glutaraldehyde } 2.5 \% \text { ) non-stained } \\
\text { ciliates } \\
{ }^{\mathrm{b}} \text { Length of the buccal cavity }\end{array}$} \\
\hline
\end{tabular}

surements are shown in Table 1). A globular macronucleus and an associated small micronucleus are in the middle of the body (Fig. 1C). The organism as a whole is highly elastic, allowing it to penetrate and move with ease in the host tissues and blood vessels. In general, ciliates from sick turbot showed abundant cell detritus within their food vacuoles, in most cases compatible with erythrocytes (Fig. 1D).

Somatic and oral infraciliature are shown in Figs. 1E,F and $2 \mathrm{~A}, \mathrm{~B}$. The somatic ciliature consists of 13 to $14 \mathrm{bi}-$ polar kineties made up of 24 to 36 kinetids (dikinetids in the anterior two-thirds of the body). A non-ciliated director-meridian is located between the first and last kineties, beginning just posterior to the scutico-vestige (4 to 6 non-ciliferous kinetids) and merging with the first kinety at the posterior pole. A cytoproct can be distinguished at the subterminal end of this meridian. At the antapical pole, a circular polar fibre connects all the kineties except the last, surrounding the polar basal-body complex. Another fibre from the last kinety continues, passing through the polar basal-body complex, until it contacts with the circular polar fibre at the level of kineties 7 or 8 . The pore of the posterior contractile vacuole opens at the posterior end of the second kinety.

The buccal cavity occupies between the anterior half and the anterior third of the body (mean buccal cavity length/body length ratio $=0.43$; range: 0.35 to 0.48 ). A paroral membrane composed of 2 parts (PM1 and PM2) separated by a narrow gap and 3 oral polykinetids (OPK1, OPK2 and OPK3) forms the buccal apparatus. PM1 extends backwards a small distance from just before the anterior end of OPK1 to about halfway along OPK3. PM2 extends from the posterior end of OPK3 to the end of the buccal cavity.

Division was by homothetogenic monotomic fission: at no stage, either during the infection or during in vitro culture, did we observe cyst formation. The initial stages of stomatogenesis observed in some ciliates revealed important changes in the organization and number of kinetosomes in PM2, and in the area of the scutico-vestige (data not shown).

\section{Clinical signs and pathology}

During the first infection outbreak, we observed turbot showing large haemorrhagic skin ulcers extending into the underlying muscle (especially in the area of the operculum). Microscopic examination of surface smears from these ulcers reveals numerous ciliates. However, it should be stressed that these ulcers were only observed in a few fish during the first outbreak, and were not observed subsequently. Bacterial infections compatible with these ulcers were not detected. Moribund fish showed darkening of the skin, and in many cases temporary alterations of swimming behaviour (including repetitive movements such as lifting the head out of the water, or swimming upside down, or in circles, or looping vertically). As noted above,
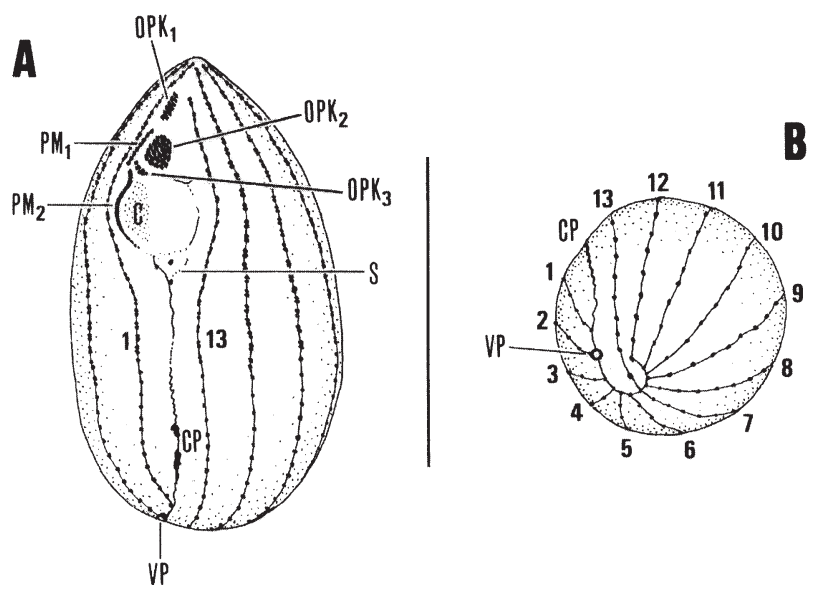

Fig. 2. Schematic drawings of Philasterides dicentrarchi causing scuticociliatosis in turbot (after wet silver impregnation; scale bar $=25 \mu \mathrm{m}$ ). (A) Somatic and oral infraciliature of the ciliate in longitudinal view. Kineties 1 and 13 are numbered. (B) Detail of somatic infraciliature and argentophilic lines at the posterior end of the ciliate. Kineties are numbered from 1 to 13 . C: cytostome; CP: cytproct; $\mathrm{OPK}_{1,2,3}$ : oral polykinetids 1,2 and $3 ; \mathrm{PM}_{1,2}$ : part 1 and 2 of paroral membrane; S: scutico-vestige; VP: pore of the posterior contractile vacuole 
many of the fish showed abdominal distension due to accumulation of ascitic fluid in the body cavity. Microscopic examination of the ascitic fluid, obtained by abdominocentesis, revealed the presence of abundant ciliates ( $>200$ per microscope field with a $10 \times$ objective). In many cases, severe uni- or bilateral exophthalmos was observed. Examination of affected eyes revealed accumulation of oedematous liquid in the periorbital region, which likewise contained abundant ciliates. Examination of fresh blood samples from the caudal vein of moribund turbot in most cases indicated systemic infection, with numerous ciliates containing ingested erythrocytes. Branchial smears likewise showed ciliates in most moribund or recently dead fish. In branchial biopsies, as noted above, numerous ciliates were observed moving through the arteries of the branchial filaments and through the capillary networks of the secondary lamellae. Some fish showed generalized infection, with ciliates being observed in squash preparations in most organs and tissues examined (i.e. not only skin, eyes, branchiae and blood, but also gastrointestinal tract, liver, spleen, kidneys, musculature, etc.). Many ciliates showed active division. Some fish showed differing degrees of softening or liquefaction of the brain. Examination of fresh brain tissues of these fish again revealed the presence of numerous ciliates.

Within the brain (Figs. 3A,B,C), ciliates were largely distributed in (1) the meninges covering the telencephalon, mesencephalon and diencephalon, (2) the optic tectum of the optic lobes of the mesencephalon, in association with foci of vascular congestion and tissue destruction (especially in the stratum griseum periventriculare and stratum fibrosum periventriculare), (3) the aqueductus mesencephali and third ventricle, and (4) in the optic nerve (both in the perineural connective tissue and in the nerve fibre bundles innervating the brain). The presence of ciliates in the meninges was typically associated with an increase in vascularization and vascular congestion, oedema and accumulation of inflammatory cellular infiltrate (principally monocytes and lymphocytes), especially in the areas showing the highest densities of ciliates. In some cases, ciliates were also observed in the glandular epithelium of the adenohypophysis (Fig. 3D), ringed by a halo of necrosis. Histopathological examinations revealed brain damage of this type in individuals showing swimming behaviour alterations.

The presence of ciliates in the intestine (Fig. 3E) caused edematous inflammation with thickening of the intestinal wall. The ciliates were principally concentrated in the lamina propria and submucosa, between connective tissue fibres and in blood vessels. In the most severe cases, ciliates almost totally replaced the connective tissue supporting the epithelial mucosa of the villi. In the serosa and muscular layer, which like- wise showed oedema, ciliates were also observed, though at lower densities, generally in association with blood vessels. In no case did we observe ciliates in the columnar epithelium. In the exocrine pancreatic tissue, ciliates were mainly concentrated in the perivascular connective tissues, although some were also associated with necrosis of the epithelium of the acinar glands (Fig. 3F).

In the liver (Figs. 4A,B), ciliates appeared in practically all tissues: (1) in vascular and perivascular connective tissue, associated with necrotizing vasculitis, including that surrounding the bile ducts, (2) in the lumina of veins and capillaries, and (3) in the parenchyma, where they caused severe necrotic foci. Ciliates were likewise observed in the vascular and perivascular connective tissues and blood in other organs, including the spleen and kidneys. In some fish, ciliates surrounded by monocytic infiltrate were found in and beneath the serous membranes that envelop the internal organs.

Histological examination of the branchiae (Fig. 4C,D) revealed the presence of ciliates in both the interlamellar and lamellar epithelium and the blood vessels. The presence of ciliates in the epithelium was associated with hyperplasia. Often, ciliates containing ingested erythrocytes were observed outside the branchiae.

In some cases, ciliates were observed in the endoand perimysial tissues of the somatic musculature, though on occasions they also appeared inside muscle fibres, associated with necrotic foci (Fig. 4E), and inside nerve fibres. In adipose tissue (Fig. 4F), ciliates were capable of penetrating into the interior of adipocytes, and were observed adhering to the inner face of the plasma membrane.

In exophthalmic eyes, oedematous changes were observed in the periorbital tissue, associated with the presence of ciliates. In some cases ciliates were detected in the glandular tissue of the choroids.

\section{DISCUSSION}

The principal morphological characteristics of the scuticociliate detected in the present study allowed us to identify this species as Philasterides dicentrarchi Dragesco, Dragesco, Coste, Gasc, Romestand, Raymond \& Bouix, 1995. This ciliate has been described as an opportunistic histophagous parasite, causing systemic disease in Dicentrarchus labrax reared in Mediterranean lagoons (Dragesco et al. 1995). The ciliates described in the present study show only minor differences from those described by these authors: specifically, our specimens showed 13 to 14 somatic kineties (vs 14 or rarely 15), and a shorter caudal cilium 
(8.7 to $13 \mu \mathrm{m}$ vs 10 to $23 \mu \mathrm{m}$ ). We do not consider that these differences are sufficient to justify consideration of our ciliates as a separate taxon to $P$. dicentrarchi, particularly bearing in mind that intraspecific biometric variability is common in ciliates (Fenchel 1990, Wiackowski et al. 1999).
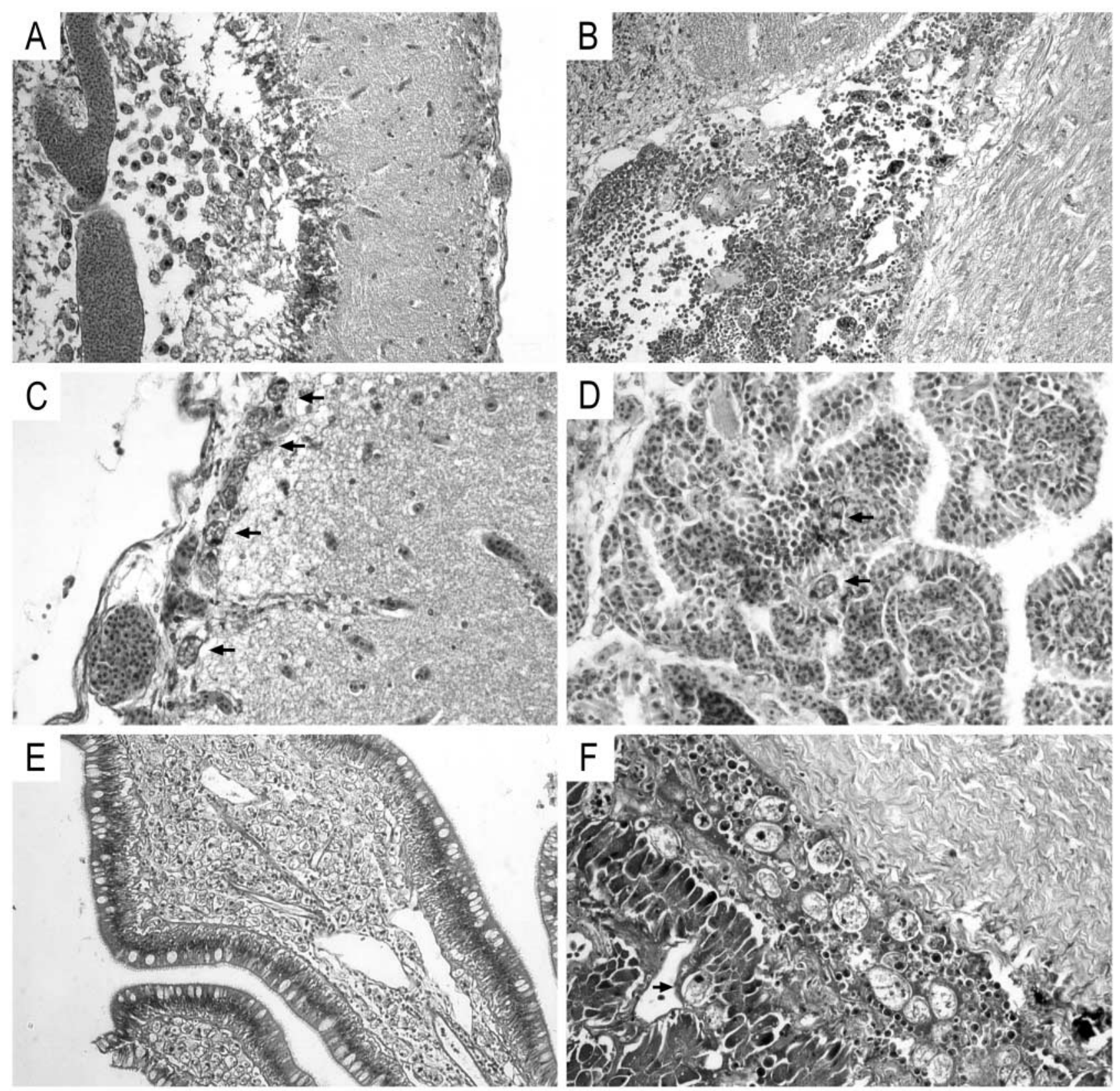

Fig. 3. Microscopic pathological changes observed in the brain (A, B, C), adenohypophysis (D), intestine (E) and exocrine pancreatic tissue (F) of turbots infected with Philasterides dicentrarchi. Sections were stained with haematoxylin \& eosin. (A) Liquefactive necrotic changes in the stratum griseum periventriculare and stratum fibrosum periventriculare of the optic tectum of the mesencephalon $(122 \times)$. Note the congested vessels in the optic tectum as wells as in the meninges. (B) Severe meningitis associated with numerous ciliates at the junction between mesencephalon and diencephalon $(122 \times)$. The ciliates are surrounded by inflammatory tissue with lymphocytic and monocytic infiltration. (C) Oedematous changes in the meninges caused by ciliates (arrows) $(244 \times)$. (D) Two ciliates (arrows) invading the glandular epithelium of adenohypophysis (244×). (E) Severe oedematous changes observed in the intestinal folds $(122 \times)$. Note that the lamina propria has been practically replaced by ciliates. (F) Perivascular cellular infiltration surrounding the ciliates in exocrine pancreatic tissue $(244 \times)$. A single ciliate (arrow) associated with a necrotic halo can be observed in the acinous glands 
There have been 2 previous reports of scuticociliate infections of cultured turbot. In the first case, reported from another Galician fish farm by Dyková \& Figueras (1994), the ciliate infection was concomitant with an outbreak of microsporidiosis due to Tetramicra brevifilum. In that outbreak, the morphology of the ciliates responsible was studied only at the histological level, and the authors were unable to reach a species-level identification. However, protargol-impregnated histological sections revealed the following characteristics: (1) pyriform or tear-shaped ciliates with a pointed anterior end, (2) 10 to 13 somatic kineties, and (3) caudal
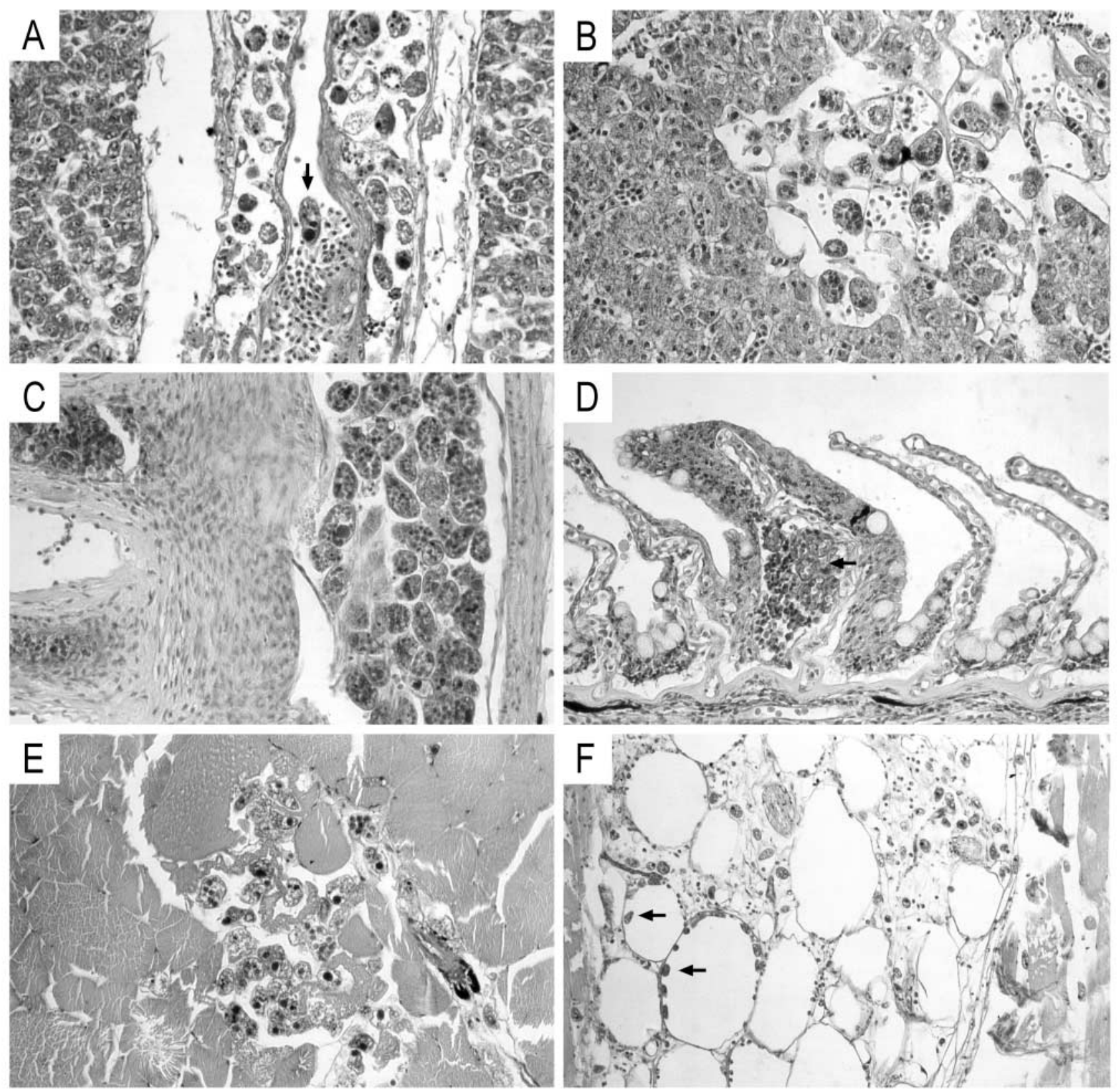

Fig. 4. Microscopic pathological changes observed in the liver (A, B), gills (C, D), musculature (E) and adipose tissue (F) of turbots infected with Philasterides dicentrarchi. Sections were stained with haematoxylin \& eosin. (A) Vasculitis caused by accumulation of numerous ciliates in the vascular connective tissue of a hepatic vein $(234 \times)$. Note the presence of a single parasite (arrow) in the lumen. (B) Severe necrosis of the hepatic parenchyma caused by the ciliate $(234 \times)$. (C) Numerous parasites in the lumina of the branchial afferent arterial system $(234 \times$ ). (D) Hyperplastic changes in the epithelial tissue of a secondary gill lamella, caused by the presence of several ciliates (arrow) $(234 \times$ ). (E) Necrotic changes in the muscular fibres $(234 \times)$. (F) Ciliates in the adipose tissue $(124 \times)$. Note the intracellular location of ciliates (arrows) in some adipocytes 
cilium not detectable. Nevertheless, both the number of somatic kineties and the apparent absence of a caudal cilium should be interpreted with caution, since protargol impregnation is not well suited for visualization of these structures. Taken together, these morphological data are insufficient to confirm that Dyková \& Figueras's ciliate was Philasterides dicentrarchi. However, the data are certainly sufficient to confirm that it was not of the genus Uronema, which is characterized by a bluntly tapered anterior end (Thompson 1964, Cheung et al. 1980, Coppellotti 1990, Munday et al. 1997).

The second previous report of a scuticociliate infection of cultured turbot was from a Norwegian fish farm (Sterud et al. 2000). Unfortunately, these authors do not supply any information on the buccal apparatus, so that species-level identification is impossible. As a result, and with the information currently available, it is not possible to decide whether Philasterides dicentrarchi is the only causal agent of scuticociliatosis in turbot. Research currently underway in our laboratory seems to suggest that this species is capable of survival in very different conditions of salinity and temperature, as has been demonstrated for other related ciliates (Uronema marinum and U. nigricans) (Cheung et al. 1980, Crosbie \& Munday 1999), so that it might also have a wide distribution in the marine environment.

From the pathological point of view, the infection described here is similar to that reported by Sterud et al. (2000), although in addition to their findings we observed that in advanced stages of infection there may also be marked necrotic destruction of the hepatic parenchyma and severe abdominal distension due to accumulation of ascitic fluid (containing abundant ciliates) in the body cavity. This latter manifestation is likewise common in sea bream infected with Philasterides dicentrarchi (Dragesco et al. 1995). If suspicion is raised by clinical signs, diagnosis may be readily achieved, without any need to sacrifice fish, by (1) abdominocentesis, (2) blood sampling from the caudal vein, and/or (3) branchial biopsy, in all cases with subsequent fresh examination of the samples. It should be stressed that in the present study ascites was always associated with abundant ciliates in the ascitic fluid.

The accumulation of ciliates observed in the present study in the principal branchial blood vessels, and particularly in the capillaries of the secondary lamellae, can be expected to have a marked obstructive effect on the lamellar capillary network, hindering uptake and transport of oxygen, so that asphyxia is probably one of the major causes of death in affected fish. In the present study we did not perform any sort of haematological study; however, the presence of numerous ciliates in the bloodstream during the systemic phase of the infection likewise clearly constitutes a severe problem, since erythrocytes are massively ingested by the ciliates. In this connection, infection of sea bream by Philasterides dicentrarchi has been shown to cause severe hypochromic anaemia (Dragesco et al. 1995).

The capacity of certain scuticociliates to feed and reproduce in the central nervous system, leading to liquefaction of brain tissue, has been reported previously in turbot (Sterud et al. 2000) and in other cultured species including the southern bluefin tuna (Munday et al. 1997). In the latter, infection by Uronema nigricans was associated with encephalitic manifestations (oedema, meningeal thickening, lymphocytic reaction, etc.) very similar to those observed in the present study. In the case of U. nigricans, a nasal route of entry has been suggested (leading to initial infection of the olfactory rosette, then migration along the olfactory nerve to the brain). In trials in our laboratory (authors' unpubl. results), we have not yet been able to achieve experimental infection of turbot by Philasterides dicentrarchi via the nasal route. Nevertheless, the following preliminary observations suggest that penetration through the cornea and/or periorbital skin may be one of the routes of invasion (at least in infections coursing with encephalitis): (1) the existence of fish with ciliates only detected in squash preparations of brain and periorbital tissue, (2) the fact that experimental injection of ciliates into the periorbital tissues consistently leads to rapid infection of the brain (authors' unpubl. results), and (3) the frequent presence of ciliates in the optic nerve and the associated perineural connective tissue of turbots with affected brains. The oxygen supersaturation sometimes obtaining in aquaculture systems may lead to small lesions of the skin, eyes and branchiae (Speare 1998), through which ciliates may penetrate, at least during the early stages of an infectious outbreak. In the outbreak of scuticociliatosis described from Norway (Sterud et al. 2000), the disease affecting large turbots was observed only in tanks in which a new culture system was being tested (with reduced water interchange and additional oxygenation of the water). The predominant pathological changes observed by these authors were encephalitis associated with softening/ liquefaction of the brain; these findings suggest that at least one of the predisposing factors for scuticociliatosis in turbot farms may be excessive oxygenation. In addition, the 2 outbreaks described in the present study occurred after a rise in temperature to above $20^{\circ} \mathrm{C}$, which may have led to stress and consequently increased susceptibility to disease. Previous studies have similarly reported outbreaks of scuticociliatosis in fish and crustaceans following alterations in water temperature (Cawthorn 1997, Munday et al. 1997).

In any case, once infection is at an advanced stage and the first deaths start to occur, ciliates are probably released into the water from cadavers, and the cadavers 
act as a food source for ciliates in the water. At this stage of an outbreak, infection may possibly occur via several routes, including the oral and branchial. As far as we are aware, to date there have been no reports of infection by Philasterides dicentrarchi by the oral route, and indeed related species like Anophryoides haemophila have been reported to be incapable of surviving in the host gut (Cawthorn 1997). Our histological observations of ciliates containing ingested erythrocytes in the interlamellar multilayered epithelium and on the branchial surface suggest that the branchiae may be a route of entry or escape. It is important to note that the route of entry may have clear effects on the type of pathology observed (e.g. encephalitis in turbot infected by the corneal/periorbital route).

The presence of protozoa in the bloodstream and in the perivascular and perineural connective tissue indicates that Philasterides dicentrarchi uses these tissues as routes for accessing almost all organs of the body. In the former case, it is probable that ciliates enter or abandon the bloodstream across the vascular endothelium, assisted by their great deformability. In this connection, in vitro experiments in our laboratory indicate that these ciliates are able to cross meshes with $5 \mu \mathrm{m}$ pore size (results not shown). To date, however, we do not know whether transendothelial migration in the fish occurs in non-directed fashion (i.e. by simple active migration of the ciliate, with the aid of its pointed anterior end) or in guided fashion (as a consequence of some sort of interaction between adhesion molecules and their ligands, as in the case of immune cells). In addition, the presence of necrotic foci around the ciliate in certain tissues, and the detection of parasites inside adipocytes and muscle fibres, suggests that proteolytic enzymes may aid within-host migration of this ciliate.

Acknowledgements. This work was supported by grant 1FD97-0032 (FEDER, Ministerio de Educación y Cultura, Spain).

\section{LITERATURE CITED}

Bassleer G (1983) Uronema marinum, a new and common parasite on tropical salt-water fishes. Freshw Mar Aquar 6:78-79

Bernard C, Fenchel T (1996) Some microaerobic ciliates are facultative anaerobes. Eur J Protistol 32:293-297

Bradbury PC (1996) Pathogenic ciliates. In: Hausmann K, Bradbury PC (eds) Ciliates: cells as organisms. Gustav Fischer Verlag, Stuttgart, p 463-477

Cawthorn RJ (1997) Overview of 'Bumper car disease'impact on the North American lobster fishery. Int J Parasitol 27:167-172

Cawthorn RJ, Lynn DH, Despres B, MacMillan R, Maloney R, Loughlin M, Bayer R (1996) Description of Anophryoides haemophila n. sp. (Scuticociliatida: Orchitophryidae), a pathogen of American lobsters Homarus americanus. Dis Aquat Org 24:143-148
Cheung PJ, Nigrelli RF, Ruggieri D (1980) Studies on the morphology of Uronema marinum Dujardin (Ciliatea: Uronematidae) with a description of the histopathology of the infection in marine fishes. J Fish Dis 3:295-303

Coppellotti O (1990) Description of Uronema marinum (Ciliophora, Scuticociliatida) from the Antarctica and observations on the nuclear events in conjugation. Polar Biol 10: $365-371$

Crosbie PBB, Munday BL (1999) Environmental factors and chemical agents affecting the growth of the pathogenic marine ciliate Uronema nigricans. Dis Aquat Org 36: 213-219

Dragesco A, Dragesco J, Coste F, Gasc C, Romestand B, Raymond J, Bouix G (1995) Philasterides dicentrarchi, n. sp. (Ciliophora, Scuticociliatida), a histophagous opportunistic parasite of Dicentrachus labrax (Linnaeus. 1758), a reared marine fish. Eur J Protistol 31:327-340

Dyková I, Figueras A (1994) Histopathological changes in turbot Scophthalmus maximus due to a histophagous ciliate. Dis Aquat Org 18:5-9

Elston RA, Cheney D, Frelier P, Lynn D (1999) Invasive orchitophryid ciliate infections in juvenile Pacific and Kumomoto oysters, Crassostrea gigas and Crassostrea sikamea. Aquaculture 174:1-14

Fenchel T (1990) Adaptive significance of polymorphic life cycles in Protozoa: responses to starvation and refeeding in two species of marine ciliates. J Exp Mar Biol Ecol 136: 159-177

Ferguson HW, Hicks BD, Lynn DH, Ostland VE, Bailey J (1987) Cranial ulceration in Atlantic salmon Salmo salar associated with Tetrahymena sp. Dis Aquat Org 2:191-195

Foissner W (1991) Basic light and scanning electron microscopic methods for taxonomic studies of ciliated protozoa. Eur J Protistol 27:313-330

Gill PA, Callinan RB (1997) Ulcerative dermatitis associated with Uronema sp. infection of farmed sand whiting Sillago ciliata. Aust Vet J 75:357

Lom J, Dyková I (1992) Developments in aquaculture and fisheries science, Vol. 26. Protozoan parasites of fishes. Elsevier, Amsterdam, p 237-288

Morado JF, Small EB (1995) Ciliate parasites and related diseases of Crustacea: a review. Rev Fish Sci 3:275-354

Munday BL, O'Donoghue PJ, Watts M, Rough K, Hawkesford $\mathrm{T}$ (1997) Fatal encephalitis due to the scuticociliate Uronema nigricans in sea-caged, southern bluefin tuna Thunnus maccoyii. Dis Aquat Org 30:17-25

Speare DJ (1998) Disorders associated with exposure to excess dissolved gases. In: Leatherland JF, Woo PTK (eds) Fish diseases and disorders, Vol. 2. Non-infectious disorders. CABI Publishing, Oxon, p 207-224

Sterud E, Hansen MK, Mo TA (2000) Systemic infection with Uronema-like ciliates in farmed turbot, Scophthalmus maximus (L.). J Fish Dis 23:33-37

Thompson JC (1964) A redescription of Uronema marinum, and a proposed new family Uronematidae. VA J Sci 15: $80-87$

Thompson JC, Moewus L (1964) Miamiensis avidus n. g., n. sp., a marine facultative parasite in the ciliate Order Hymenostomatida. J Protozool 11:378-381

Wiackowski K, Hryniewiecka-Szyfter Z, Babula A (1999) How many species are in the genus Mesanophrys (Protista, Ciliophora, facultative parasites of marine crustaceans)? Eur J Protistol 35:379-389

Yoshinaga T, Nakazoe J (1993) Isolation and in vitro cultivation of an unidentified ciliate causing scuticociliatosis in Japanese flounder (Paralichthys olivaceus). Gyobyo Kenkyu 28:131-134

Submitted: December 7, 2000; Accepted: March 5, 2001

Proofs received from author(s): August 3, 2001 